\title{
A Study on Student' Speaking Ability of Telling Historical Experience At MA Nurul Wathan Pelangiran
}

\author{
Yogi Arisandi, \\ English Department State Islamic University of Sultan Syarif Kasim Riau \\ yogi.arisandi@uin-suska.ac.id \\ Harum Natasha \\ English Department State Islamic University of Sultan Syarif Kasim Riau \\ harum.natasha@uin-suska.ac.id
}

\begin{abstract}
According to 2013 curriculum, the English learning goal is to develop the students' potential to have the communicative competence in interpersonal, transactional, and functional in written and spoken form. However, according to the preliminary study at Islamic Senior High School Nurul Wathan Pelangiran, the students have difficulties in reaching the passing grades of English; 75. Another thing is teh students have difficultiesnin producing proper vocabularies and good pronunciation. They did not know the appropriate vocabularies while speaking and they often failed to pronounce some words properly. These problems appear to be in educational system where the students have learnt English speaking since the elementary school, but their ability to speak is still low. This research was aimed to find out the students' speaking abillity of telling historical experience at tenth grade in English Classroom and to know the most dominant component of students' speaking ability of telling experience at tenth grade of MA Nurul Wathan Pelangiran. This research is a descriptive quantitative research and in collecting the data, the instrument was speaking test. The sample was the total population from social class. The researchers found that the mean score of students' speaking ability of telling historical experience is 52.50 , and categorized as less level. The most dominant component of students' speaking ability is vocabulary with mean score 2.86 or $57.2 \%$. Students' speaking is mostly on less level. So the students need to prepare and practice more about speaking. They often pause their speaking during the test, or the students did find it difficult to deal with vocabularies related to historical experience.
\end{abstract}

Keywords: Speaking Ability, Telling Historical Experience 


\section{A. INTRODUCTION}

One of the essential skills of English is speaking. The ability to speak in English is considered to be important in real life, in which we use English is to convey a meaning as the way to express ideas, feelings, and thoughts by language orally. It cannot be separated in the real life because all we do involves language to speak. Efrizal (2013) stated that speaking includes language use that must be applied in real communication. For some people speaking English is hard due to the lack of expose especially in country which English is a foreign language.

In addition to the statement above, speaking is a complex process skill among the other three skills, no doubt that many students get difficulties in learning speaking. It is a complex thing which needs several aspects. According to Brown (2011), speaking involves aspects such as fluency, accent, vocabulary, grammar, and comprehension. Since it is a complex skill, it needs more practice as well as the teaching should be facilitated. In Indonesian, speaking is one of subject taught from junior high school up to university level.

Islamic senior high school Nurul Wathan Pelangiran (MA Nurul Wathan Pelangiran) is one of Senior high school in Pelangiran which is taught twice a week, 90 minutes for every meeting which means 180 minutes in a week. The school provides English lesson, including speaking lesson. Speaking is one of English skills that should be mastered by students in the school. According to 2013 curriculum, the goal of learning English is to develop the students' potential to have the communicative competence in interpersonal, transactional, and functional in written and spoken form. Historical experience is the theme for recount text that the students should learn at the tenth grade. The goal is to produce English spoken about recount regarding to historical experiece, concerning on social function, organization and language component correctly based on its context.

However, based on researchers' preliminary study at the school, the researcher did interview and observation to know how their speaking ability during the class was, and whether or not they face difficulties in speaking English especially of telling their historical experience. As a result, it is concluded that: First, they have difficulties in reaching students' passing grade in English, 75 points. Second, the students have difficulties in producing good vocabularies and pronunciation. They didn't know kinds of vocabularies to say while speaking. Last, they often failed to pronounce some words properly in speaking. These problems appear to be in educational system where the students have learnt English speaking since the elementary school, but their ability to speak is still low. In essence, the learning is not effective and succeeded since the student doesn't achieve the standard as what the curriculum have required.

Based on the preliminary research the writers found some problems, especially in speaking ability as follows: 1) Some of the students are not able to speak with appropriate vocabulary, 2) Some of the students are not able to speak grammatically correct, 3) Some of the students are not able to pronounce the word correctly, 4) Some of the students are not able to comprehend English phrases, and 5) 
Some of the students feel afraid in speaking performance

Based the explanation above the writer was interested in conducting a research on students' speaking ability of telling historical experience at MA Nurul Wathan Pelangiran.

\section{B. Theoritical Framework}

\section{Speaking}

According to Haidara (2014), speaking is so intertwined with daily interactions that it is not easy to give a unique and concise definition to it. Besides, Lackman (2010) stated that someone's' speaking can be mentionable well, if it uses speaking skill when we are talking. The speaking components is as follows: fluency, accuracy with words \& pronunciation, using functions, appropriacy, turntaking skills, relevant length, responding and initiating, repair and repetition, range of words and grammar, discourse markers.

According to Derakhshan, Khalili and Beheshti (2016), there are two categories in speaking skill: accuracy and fluency. Accuracy consists of using vocabulary, grammar and pronunciation through some activities, fluency take into account "the ability to keep going when speaking spontaneously".

Speaking ability is very important in the context of English learning. It is because through verbal language, one enables to express his/her ideas and thoughts and being able to speak. It is one of the indicators of mastering the language (Fauzan, 2016). According to Bahardovar and Omdivar (2014), speaking is the process of building and sharing meaning through the use of verbal and non-verbal symbols, in a variety of contexts. Speaking is a crucial part of second language learning and teaching, it is an art of communications and one of four productive skills that must be mastered in learning foreign language. Pertaining to this statement, Manurung and Darmawan (2014) stated that speaking is a productive skill that needs input before it is produced. Speaking is productive skill in the oral mode. It is, like the other skills, more complicated than it seems at first and involves more than just pronouncing words (Bashir, Azeem \& Dogar, 2011).

\section{Speaking Ability}

According to Bashir (2011), speaking is the way of someone to convey the message through the words by mouth. Meanwhile, Efrizal (2012) explained speaking is as one way to transfer our ideas or message to interlocutor orally. Speaking ability is competence of someone to speak well. In line with Lackman (2010), speaking ability is when someone doing communicate with interlocutor with good language.

According to Kusmaryanti (2008), speaking ability is a skill to communicate a speech articulation or to speak a talk for expressing an idea and a message. Thornbury (2005) said that speaking ability is a proficiency of using the language orally. Many language learners regard speaking ability as the measure of knowing a language. These learners define fluency as the ability to converse with others, much more than the ability to read, write or comprehend oral language. Regarding to this statement, Murcia (2001) stated that the ability to speak a language is the most basic means of human communication. It can be concluded that speaking ability is a 
skill, which is communicating the speech sound for expressing and conveying a messages or ideas.

\section{Types of Speaking}

Brown (2003) has

categorized basic type of speaking into five types as follows:

1. Imitative: imitative is the basic one. It is done by children especially at kindergarten and elementary student because the students just try to copy a word or a sentence. At one end of a continuum of types of speaking performance is the ability to simply parrot back (imitate) a word or phrase or possibly a sentence. Kusmaryanti (2008) adds that this type of speaking performance is the ability to imitate a word or phrase or possibly a sentence.

2. Intensive: the production of short stretches of oral language designed to demonstrate competence in narrow band of grammatical, phrasal, lexical or phonological, relationships. It includes directed response task, reading aloud, sentence, and dialogue completion; limited picture-cued task including simple sequences; and translation up to the simple sentence level.

3. Responsive : responsive assessment task include interaction and test comprehension but at the somewhat limited level of very short conversation, standard greetings and small talk, simple requests and comments, and the like.

4. Interactive: the difference between responsive and interactive speaking is the length and complexity of the interaction, which sometimes include multiple exchanges and or multiple participants. Interaction can take the two forms of transactional language, which has the purpose of maintaining social relationships.

5. Extensive (monologue): Extensive oral production tasks include speeches, oral presentation, and storytelling, during which the opportunity for oral interaction form listeners is either highly limited (perhaps to nonverbal responses) or ruled out altogether.

\section{Components of Speaking Ability}

According to Hughes (1989), there are five components of speaking namely accent, grammar, vocabulary, fluency, comprehension. Meanwhile, Richard and Schmidt (2002) provide the explanation, as follows:

\section{1) Accent}

The special registers and genres of language used in the learning of academic subject matter in formal schooling contexts.

2) Grammar

Grammar describes the speaker's knowledge of the language. It looks at language in relation to how it may be structured in the speaker's mind, and which principles and parameter are available to the speaker when producing the language.

3) Vocabulary

It refers to a set of lexemes, including single words, compound word and idioms.

4) Fluency

The features which give speech the qualities of being natural and normal, including native-like use of pausing, rhythm, intonation, stress, rate of speaking, and use of interjections and interruptions.

5) Comprehension

It refers to the identification of the intended meaning of written or spoken communication. 
Pertaining to Harmer (2001, p.269271), there are two elements of speaking that we should pay attention to have a good ability to speak fluently. They are:

a. Language Feature consists of four parts. Firstly, connected speech. In connected speech sounds are modified (assimilation), omitted (elision), added (linking r), or weakened (through contractions and stress patterning).

Secondly, Expressive devices. The use of these devices contributes to the ability to convey meanings. They allow the extra expression of emotion and intensity. The students should be able to deploy at least some of such supra segmental features and devices in the same way if they are to be fully effective communicators. Thirdly, lexis and grammar. It supplies the variety of phrases for different functions such as agreeing or disagreeing, expressing surprise, shock, or approval. Where the students are involved in specific speaking context such as a job interview, we can prime them, in the same way, with certain useful phrases which they can produce at various stages of an interaction. Fourthly, negotiation language, it is used to seek clarification and to show the structure of what we are saying.

b. Mental/Social Processing consists of three part, first language processing. Language processing involves the retrieval of words and phrases from memory and their assembly into syntactically and propositionally appropriate sequences. It helps students to develop habits of rapid language processing in English. Second, interacting with other that speaking also involves a good deal of listening, an understanding of how the other participants are feeling, and knowledge of how linguistically to take turns or allow others to do so. Third, information processing. The teacher needs to be able to process the information. It should be remember that this instants response is very culturespecific, and is not prized by speakers in many other language communities.

\section{Assessing Speaking Ability}

Speaking is a complex skill requiring the simultaneous use of different ability which often develops at different roles. Speaking is skill recognized in analysis of speech process that is pronunciation, grammar, vocabulary, and comprehension. According to Hughes (2003) there are some components that should be considered in giving students' score: they are accent, grammatical, vocabulary, fluency, and comprehension.

The scoring process will be done by two raters by using the indicators of speaking ability as mentioned below: 
1) Accent

Table II.I

Table of Accent Score

\begin{tabular}{|c|c|}
\hline Score & Requirement \\
\hline 1 & Pronunciation frequently unintelligible \\
\hline 2 & $\begin{array}{l}\text { Frequent gross error and a very heavy accent make } \\
\text { understanding difficult, require frequently repetition }\end{array}$ \\
\hline 3 & $\begin{array}{l}\text { "foreign second" requires concentrated listening, and } \\
\text { mispronunciations lead to occasional misunderstanding and } \\
\text { apparent error in grammar of vocabulary }\end{array}$ \\
\hline 4 & $\begin{array}{l}\text { Marked " foreign accent" and occasional mispronunciation } \\
\text { which do not interfere with understanding }\end{array}$ \\
\hline 5 & $\begin{array}{l}\text { No conspicuous mispronunciations, but would not be taken for } \\
\text { a native speaker. }\end{array}$ \\
\hline
\end{tabular}

2) Grammar

Table II.2

Table of Grammar Score

\begin{tabular}{cl}
\hline Score & \multicolumn{1}{c}{ Requirement } \\
\hline $\mathbf{1}$ & $\begin{array}{l}\text { Grammar almost entirely inaccurate except in stock phrase } \\
\text { Constant errors showing control of very view major patterns and } \\
\text { frequently preventing communication. }\end{array}$ \\
$\mathbf{3}$ & $\begin{array}{l}\text { Frequent errors showing some major pattern uncontrolled and } \\
\text { causing occasional irritation and misunderstanding. }\end{array}$ \\
$\mathbf{4}$ & $\begin{array}{l}\text { Occasional errors showing imperfect control of some pattern but } \\
\text { no weaknesses that causes misunderstanding }\end{array}$ \\
$\mathbf{5}$ & Few errors, with no patterns of failure \\
\hline
\end{tabular}

3) Vocabulary

Table II.3

Table of Vocabulary Score

\begin{tabular}{|c|c|}
\hline Score & Requirement \\
\hline 1 & Vocabulary inadequate for even the simplest conversation \\
\hline 2 & $\begin{array}{l}\text { Vocabulary limited to basic personal and survival areas (time, } \\
\text { food, transportation, family, etc.) }\end{array}$ \\
\hline 3 & $\begin{array}{l}\text { Choice word sometimes inaccurate, limitations of vocabulary } \\
\text { prevent discussion of some common professional and social } \\
\text { topics. }\end{array}$ \\
\hline 4 & $\begin{array}{l}\text { Professional vocabulary adequate to discuss special interest, } \\
\text { general vocabulary permits discussion of any non-technical } \\
\text { subject with some circumlocution. }\end{array}$ \\
\hline 5 & $\begin{array}{l}\text { Professional vocabulary broad and precise; general vocabulary } \\
\text { adequate to cope with complex practical problem and varied } \\
\text { social situations }\end{array}$ \\
\hline
\end{tabular}


4) Fluency

Table II.4

Table of Fluency Score

\begin{tabular}{ll}
\hline Score & \multicolumn{1}{c}{ Requirement } \\
\hline $\mathbf{1}$ & $\begin{array}{l}\text { Speech is so halting and fragmentary that conversation is } \\
\text { virtually impossible. }\end{array}$ \\
$\mathbf{2}$ & $\begin{array}{l}\text { Speech is very slow and uneven accept for short or routine } \\
\text { sentences' }\end{array}$ \\
$\mathbf{3}$ & $\begin{array}{l}\text { Speech is fluently hesitant and jerky; sentences may be left } \\
\text { uncompleted }\end{array}$ \\
$\mathbf{4}$ & $\begin{array}{l}\text { Speech is occasionally hesitant, with some unevenness caused by } \\
\text { rephrasing and grouping for words. }\end{array}$ \\
Speech is effortless and smooth, but perceptively non-native an \\
speed and evenness
\end{tabular}

5) Comprehension

Table II.5

Table of Comprehension Score

\begin{tabular}{ll}
\hline Score & \multicolumn{1}{c}{ Requirement } \\
\hline $\mathbf{1}$ & Understands too little for the simples types of conversation. \\
$\mathbf{2}$ & $\begin{array}{l}\text { Understands only slow, very simple speech on common social } \\
\text { and touristic topic; require constant repetition and rephrasing. }\end{array}$ \\
$\mathbf{3}$ & $\begin{array}{l}\text { Understands careful, somewhat simplified speech when engaged } \\
\text { in a dialogue, but may require considerable repetition and }\end{array}$ \\
$\mathbf{4}$ & $\begin{array}{l}\text { rephrasing. } \\
\text { Understands quit well normal educated speech when engaged in a } \\
\text { dialogue, but may require occasional repetition and rephrasing. }\end{array}$ \\
$\mathbf{5}$ & $\begin{array}{l}\text { Understands everything in normal educated conversation except } \\
\text { for very colloquial or low-frequency items, or exceptionally rapid } \\
\text { or slurred speech }\end{array}$ \\
\hline
\end{tabular}

The speaking result will be evaluated by concerning five components and each other components have score or level. Each component has 5 as the highest score and the total of the components will be 20 . The specification of the test is as follows:

Table II.5

The Specification of Conversion Score

\begin{tabular}{|c|c|c|}
\hline No & Speaking Ability Component & The maximum score \\
\hline a. 1 & $\overline{\text { Accent }}$ & 20 \\
\hline b. 2 & Grammar & 20 \\
\hline c. 3 & Vocabulary & 20 \\
\hline 4 & Fluency & 20 \\
\hline 5 & Comprehension & 20 \\
\hline & Total & 100 \\
\hline
\end{tabular}




\section{d. Historical Experience As a Learning Material of Speaking}

In 2013 Curriculum for tenth grade students, historical experience or story is one of topics in learning English in which it is expected to be able to cultivate behavior in the target competence. Then, the social function of this topic is to tell, report, and share about experience.

Students are expected to produce English spoken, where it tells story based on several parts as follows:

a. Orientation

Tell about background information about who, where, when events or events occurred.

b. Events

Tell a series of events that occur in chronological order.

c. To close the story, we can give our opinion about the story.

In addition, the language used in English spoken about telling historical experience covers several components:

a. Past tense: like went, departed, would, woke up, and so on.

b. Adverb and adverbial phrase to express time, place and method, such as: last September, Pari Island, on then second day, and so on.

c. Conjunction and time connective to sort events such as: and, before, then, after that, and so on.

d. Phrase, intonation, word stressing, spelling, punctuation

\section{A. Relevant Research}

Some investigations were conducted by some researchers dealing with students English both speaking performance and ability due to its significance. In some recent years, the study of English speaking has become increasingly chosen topic area in research. Relating to this research, some previous researches were conducted by some previous researchers related to this topic.

First, a research by Rahmawati (2017), Syiah Kuala University, Banda Aceh, entitled improving English Speaking Ability Using the TeamGames-Tournament Technique. The results obtained, only $12 \%$ (3 students) passed the KKM in the pre-test and $88 \%$ (21 students) did not pass. The passing percentage increased to $54 \%$ (13 students) after the 1 st cycle whilst 46\% (11 students) still did not pass the KKM. After the last cycle, the percentage that passed the KKM increased to $96 \%$ (23 students) and only $4 \%$ (1 student) did not pass. Thus the implementation of the TGT technique over two cycles was deemed highly successful, not only the Grade X students improved their speaking ability but also the teacher improved her ability to teach speaking English. Accordingly this study recommends that other teachers of speaking English EFL should also try using the TGT technique.

Second, another relevant study was conducted by Astriwulan (2018), State Islamic University of Sultan Syarif Kasim Riau. Entitled "The Correlation Between Students' Speaking Interest and Their Speaking Ability". The finding revealed that the probability of score sig.t is 0.001 , is smaller than the significant alpha of 0.05 (sig.t $<0.05$ ). It means that $\mathrm{H}_{0}$ is rejected and $\mathrm{H}_{\mathrm{a}} \mathrm{is}$ accepted. In other words, there is a significant correlation between self-assessment and speaking ability. The researcher has find out that $26.52 \%$ speaking ability of the tenth grade of Plus Senior High School of Riau Province is influenced by speaking 
interest. Then, the other $73.48 \%$ is influenced by other factors.

Third, another relevant study was conducted by Pamujo Effa Kusdianang and Dwi Anggani Linggar Bharati (2016), English Language Education Postgraduate Program Universitas Negeri Semarang, Indonesia ,entitled "Improving Students' Motivation in Speaking Ability By Using Story Retelling". The result of studentse speaking skill showed some improvements as follows; from precycle to cycle 1 increased $6 \%$. From cycle 1 to cycle 2 increased $9.92 \%$ and from cycle 2 to cycle 3 increased 7.31 $\%$. Fourthly, based on the observation, the students who have high motivation increase from $37 \%$ in the recycle to 40 $\%$ in the first cycle then become $70 \%$ in cycle 2 and finally $90 \%$ in cycle 3 . The result of students ${ }^{\text {ee }}$ motivation based on the questionnaire from pre-cycle to cycle 1 increased $9.29 \%$. From cycle 1 to cycle 2 increased $10.97 \%$ and from cycle 2 to cycle 3 increased $4.74 \%$. Based on the findings, story retelling could improve students' motivation in speaking ability of the second semester students of SMAN Jatitujuh Majalengka academic year 2014/2015.

Next relevant study was conducted by Yohanes Paulus Florianus Erfiani (2017), Universitas Timor, Kefamenanu, NTT, Indonesia. His research entitled "Improving Students' Speaking Ability Through Storytelling Model In Universitas Timor". Based on the data analysis, there is a significance improvement in each cycle. The average of students' speaking ability in Cycle I is $67 \%$. That average is taken from vocabulary aspects $68 \%$, pronunciation aspect $67 \%$ and grammatical aspect $66 \%$. Then, in cycle II the average of student's mark is increasing into $81 \%$ that consist of vocabulary aspect $83 \%$, pronunciation aspect 795 and grammatical aspect $81 \%$. Therefore, this research indicates that storytelling model can improve the speaking ability of second semester students in Uiversitas Timor.

Next relevant study was conducted by Sity Romlah (2018), SMP Negeri 1 Kedawung Cirebon, West Java- Indonesia, entitled "Improving Students' Speaking Skill on Transactional / Interpersonal Text of class VII A SMP Negeri 1 Kedawung Kabupaten Cirebon Through Talking Stick". The result showed that in general there was an improvement of classical learning mastery of students; speaking skill of transactional/interpersonal text about $35,36 \%$. This was done by comparing each test on each treatment. The result of cycle 1 showed 19 students of VII A reached classical mastery of learning for about $79,54 \%$. The average score of cycle 1 was 79 and the average score 2 was 81 with very good category. The data of students' responses reached active criteria on cycle 1 and very good criteria on cycle 2. The teacher's performance reached score 72 on cycle 72 with very good criteria, and 89 on cycle 2 with very good criteria. Based on the gained data, it can be said that the research had achieved its target and the improvement of students' speaking skill on transactional /interpersonal text of class VII A of SMP Negeri 1 Kedawung kabupaten Cirebon through Talking Stick was successful.

Next relevant study was conducted by Kerisnin Otoyo (2018), English Instructor at Gloria English Course Palembang, South Sumatera, entitled "The Use of Gallery Walk to Enhance Speaking Ability of the Eleventh Grade Students of State Madrasyah Aliyah". The result of this 
study showed that (1) significant improvement on the eleventh grade students' speaking ability before and after the treatment at was found since the p-output was lower than 0,05 ; and (2) significant difference from students' posttest score in experimental and control group on the eleventh grade students' speaking ability taught by using Gallery Walk Strategy and teacher's strategy were found since the p-output was lower than 0,05 . In short, Gallery Walk strategy can be implemented as one of the strategies since it can enhance students' speaking ability.

$\begin{array}{rrl}\text { Next relevant } & \text { study was } \\ \text { conducted by Rani } & \text { Candrakirana } \\ \text { Permanasari } & (2014), & \text { Unniversitas }\end{array}$ Negeri Semarang, entitled "Improving Students' Speaking Skill Through Three Steps Interview Technique. (An Action Research of the Tenth Grade Students of SMK Negeri 9 Semarang in the Academic Year of 2013-2014)". The result of the study showed that the students' responses in learning speaking was good. They enjoyed the activities using Three Steps Interview Technique in class by having a discussion, sharing, and cooperating well. The students' improvement was proved by their speaking test results which increased from test to test. In pretest, all of students final scores were under 50. In the cycle one test, no one of them got final score less than 50. From the cycle two test, most of the students got final score more than 70 . Then, the data of post-test showed that all of the students got score more than 70 .

The last relevant study was conducted by Armasita (2017), The State Islamic University of North Sumatra Medan, entitled "Improving Students' Speaking Skill in English Lesson By Using Action Learning
Strategy at VIII-A grade of MTs PAB 1 Helvetia". The result of this research showed that there was increasing of students in speaking skill. The mean of pre-test was 59. The mean of post-test 1 was 75.04. the mean of post-test 2 was 82.11. It indicated that the scores and the mean in second cycle were better than the first cycle. The percentage of students who got point $>75$ also grew up. In the pre-Test, the students who got point $>75$ up were 4 students $(9.09 \%)$. In the post-test of cycle 1 students who got point $>70$ up were 30 students $(68.18 \%)$. The post-test of cycle 2 , students who got point $>75$ were 38 students $(86.36 \%)$. In other words, the students' ability in speaking improved and became well in the first meeting to the next meeting.

It seems no research directed to investigate the students' speaking ability of telling historical experience at senior high school level. Therefore, this research is expected to give a contribution to the gap made by the previous researchers and reveal the current issue at the school.

\section{Operational Concept}

Operational concept is main element to avoid misunderstanding and misinterpretation in scientific research because a concept is a diagram to operate the abstract from in this research plan to measure. In this research, the variable is Speaking Ability. According Hughes (1989), there are five components of speaking, as follows:

a. The student has an ability to produce acceptable pronunciation in speaking. (Accent)

b. The student has an ability to use correct grammar in speaking. (Grammar) 
c. The student has an ability to use proper words in speaking. (Vocabulary)

d. The student has an ability to produce speech without filtering and pausing. (Fluency)

e. The student has an ability to express the comprehensible ideas. (Comprehension)

\section{RESEARCH METHOD}

\section{Research Design}

This research is a quantitative research, specifically descriptive quantitative study. According to Priyono (2016), the purpose of this research is to describe phenomenon and symptom in detail. Descriptive quantitative method is commonly used to describe phenomenon that occurs in the natural setting. This research was conducted by investigating the students' speaking ability of telling historical experience at tenth grade at MA. Nurul Wathan Pelangiran

\section{Subject of the Research}

Subject of this research was tenth grade students of MA .Nurul Wathan Pelangiran.

\section{Object of the Research}

The object of this research was the students' speaking ability of telling historical experience at tenth grade at MA. Nurul Wathan Pelangiran.

\section{Population and Sample of the Research}

\section{Pop ulation of the Research}

The population of this research was the tenth grade students at Islamic Senior High School Nurul Wathan Pelangiran in academic year 2018/2019. The tenth grade students at Islamic senior High school Nurul Wathan Pelangiran contain 32 students.

\section{The Sample of the Research}

In this research, the researcher used total sampling. According to Arikunto (2002), if population is less than 100, the sample is taken all. Thus, the researcher will take all population as the sample of this research which consists of 32 students.

\section{Technique of Data Collection}

In order to collect the data, the researcher used a test. According to Nunan (2007), test is employed to measure all kinds of abilities, interests, and works. In this case, the researcher will conduct speaking test to know students' speaking ability involving their pronunciation, grammar, fluency, and comprehension.

In testing students speaking ability, the students asked to tell story about their experience.

\section{Technique of Data Analysis}

The researcher used quantitative analysis, then, the collected data is analyzed by using quantitative analysis as well. The score was scored by using the following formula:

$$
\bar{x}=\frac{\sum x}{N}
$$

Where:

$\sum \mathrm{x}=$ Total of students score

$\mathrm{N}=$ Total of students 
Classification for students' speaking ability of telling historical experience can be seen below:

Table III.13

Scale of the Students' Speaking Ability

\begin{tabular}{ccc}
\hline No. & Score & Category \\
\hline 1 & $80-100$ & Very good \\
2 & $66-79$ & Good \\
3 & $56-65$ & Enough \\
4 & $40-55$ & Less \\
5 & $30-39$ & Fail \\
\hline
\end{tabular}

Adopted from (Arikunto, 2013, p.281, Dasar dasar Evaluasi Pendidikan)

Meanwhile, to analyze the data, the researcher used a formula from Hariyadi (2009). The researcher will percentage the data of the dominant component of students' speaking ability in telling historical experience by using following formula:

Note: $\mathrm{P}=$ Percentage

$$
\mathrm{P}=\frac{f}{N} \times 100 \%
$$

$\mathrm{N}=$ Number of cases (number of frequency)

$\mathrm{F}=$ Frequency

\section{Validity and Reliability}

\section{a. Validity}

Cresswell (2011) stated that validity is the individual's score from an instrument that make sense, meaningful; enable you, as the researcher, to draw conclusion from the sample you are studying to the population. It means that validity is the extent to which inference made from assessment results are appropriate, meaningful, and useful in the terms of the purpose of the assessment. To validate the speaking test of this research, the researcher used content validity. Brown (2012) described that construct validity means the validity that relates to the ability of instrument which is used to measure aspect such us intelligence, motivation, anxiety, an others.

\section{Reliability}

Reliability has to do with accuracy of measurement. This kind of accuracy is reflected in obtaining the similar results when measurement was repeated on different or by different person. The characteristic of reliability is sometimes termed consistency (Brown, 2003). To find out the reliability of speaking test, the researcher used inter-rater reliability formula because the researcher will use two raters in assessing and giving the score of the students' ability of telling historical experience. Inter-rater reliability occurs when two or more scorers yield inconsistent scores of the same test, possibly for lack of attention of scoring criteria, inexperience, inattention, or even preconceived biases. The researcher will compare scores from two raters (rater 1 and rater 2) in order to find out if the scores will be similar or different. After comparing the score, the researcher will determine how close the scores from two raters. 
Table III.2

Level of Acceptable Reliability

\begin{tabular}{ccc}
\hline NO & Reliability Value & Level \\
\hline $\mathbf{1}$ & $>0.90$ & Very high \\
$\mathbf{2}$ & $0.80-0.90$ & High \\
$\mathbf{3}$ & $0.70-0.79$ & Reliable \\
$\mathbf{4}$ & $0.60-0.69$ & Marginally/Minima \\
$\mathbf{5}$ & $<0.60$ & lly \\
\multicolumn{2}{l}{ Cohen, Manion, \& Morison,2007,p.506) }
\end{tabular}

To obtain the reliability of the speaking test, the researcher applied SPSS 21 application to find the reliability of the test based on Alpha Cronbach technique.

Table III.3

Reliability Statistic of Speaking Ability Test

\begin{tabular}{cc}
\hline Cronbach's Alpha & N of Items \\
\hline 0.884 & 2 \\
\hline
\end{tabular}

From the table above, it shows that the calculation of rater 1 and rater 2 is 0.883 . The value is higher than the standard Cronbach's alpha which is 0.60 . Therefore, it can be concluded the test is reliable, and the level of reliability is high.

\section{DATA PRESENTATION AND DATA ANALYSIS}

\section{A. Data Presentation of Students' Speaking Ability of Telling Historical Experience}

This research consists of one variable that is students' ability of telling historical experience. To obtain information about the students' ability of telling historical experience and the most dominant component of their speaking ability at the tenth grade of MA Nurul Wathan Pelangiran the researcher used a speaking test. The result of the students' test can be seen in the following table:

Table IV.1

Students' Speaking Ability Score

\begin{tabular}{cccc}
\hline Students & Rater 1 & Rater 2 & $\begin{array}{c}\text { mean } \\
\text { Score }\end{array}$ \\
\hline Student 1 & 52 & 48 & 50 \\
Student 2 & 44 & 40 & 42 \\
Student 3 & 44 & 40 & 42 \\
Student 4 & 56 & 52 & 54 \\
Student 5 & 60 & 60 & 60 \\
Student 6 & 56 & 60 & 58 \\
Student 7 & 60 & 56 & 58 \\
Student 8 & 60 & 60 & 60 \\
Student 9 & 48 & 48 & 48 \\
Student 10 & 44 & 40 & 42 \\
Student 11 & 60 & 64 & 62 \\
Student 12 & 52 & 44 & 48 \\
Student 13 & 44 & 40 & 42 \\
Student 14 & 56 & 52 & 54 \\
\hline
\end{tabular}


Yogi Arisandi, Harum Natasha - A Study on Student' Speaking Ability of Telling ...

\begin{tabular}{llll}
\hline Student 15 & 56 & 52 & 54 \\
Student 16 & 44 & 48 & 46 \\
Student 17 & 52 & 48 & 50 \\
Student 18 & 52 & 56 & 54 \\
Student 19 & 60 & 52 & 56 \\
Student 20 & 60 & 60 & 60 \\
Student 21 & 60 & 64 & 62 \\
Student 22 & 52 & 52 & 52 \\
Student 23 & 44 & 44 & 44 \\
Student 24 & 48 & 44 & 46 \\
Student 25 & 52 & 60 & 56 \\
Student 26 & 48 & 44 & 46 \\
Student 27 & 60 & 60 & 60 \\
Student 28 & 48 & 44 & 46 \\
Student 29 & 52 & 60 & 56 \\
Student 30 & 52 & 56 & 54 \\
Student 31 & 60 & 64 & 62 \\
Student 32 & 52 & 60 & 56 \\
\hline
\end{tabular}

To make it clear, the researcher makes up the interval score distribution of the students' speaking ability of telling historical experience score. To find the interval score, the researcher computed the range score. Then, the range was divided by class interval. The following chart is the data of interval

Chart IV.1

Frequency Score of Students' Speaking Ability

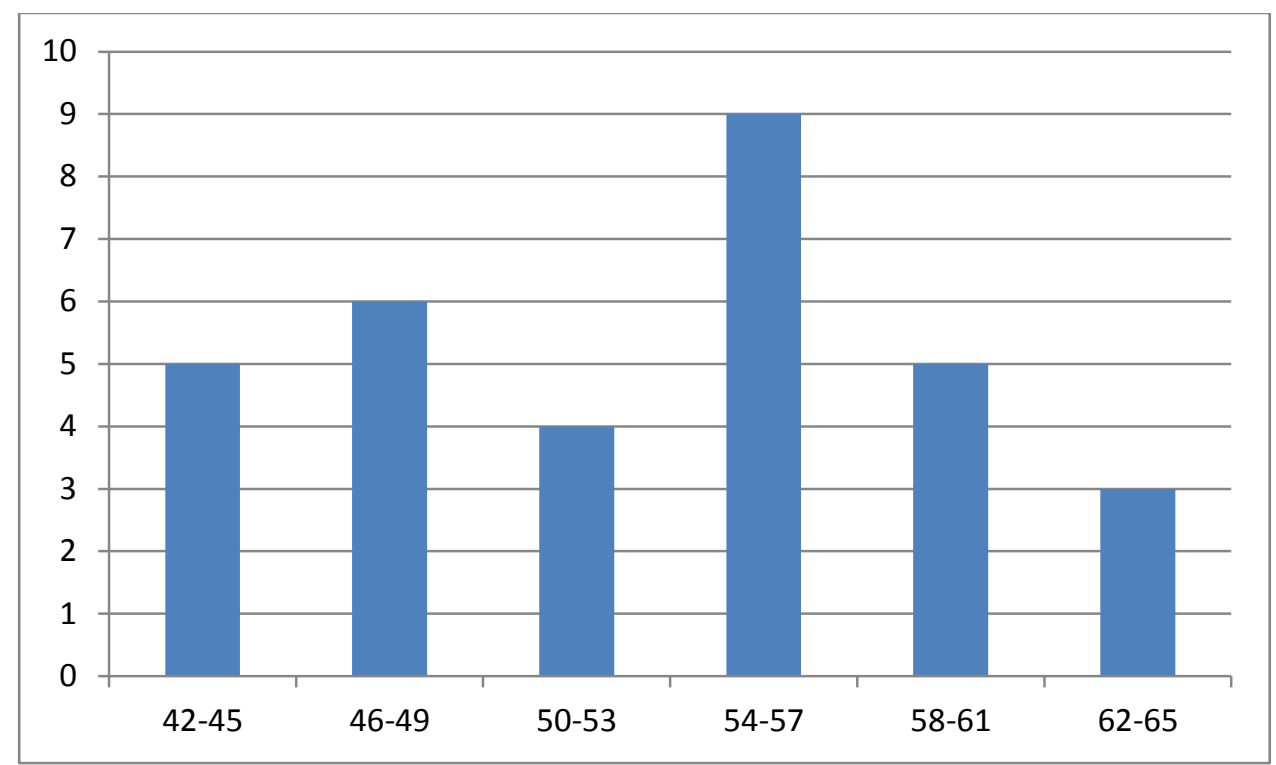

score distribution of students' speaking ability of telling historical experience. 
It can be seen, at the interval score of $42-45$, there are 5 students. At the interval score 46-49 there are 6 students. At the interval score 50-53, there are 4 student. At the interval score of 54-57, there are 9 students. At the interval score of 58-61, there are 5 students. And at the interval score of 62-65, there are 3 students. Meanwhile, the chart below presents the percentage of students' interval score distribution of students' speaking ability.

\section{Chart IV.2}

\section{Percentage of Interval Score Distribution of Students' Speaking Ability}

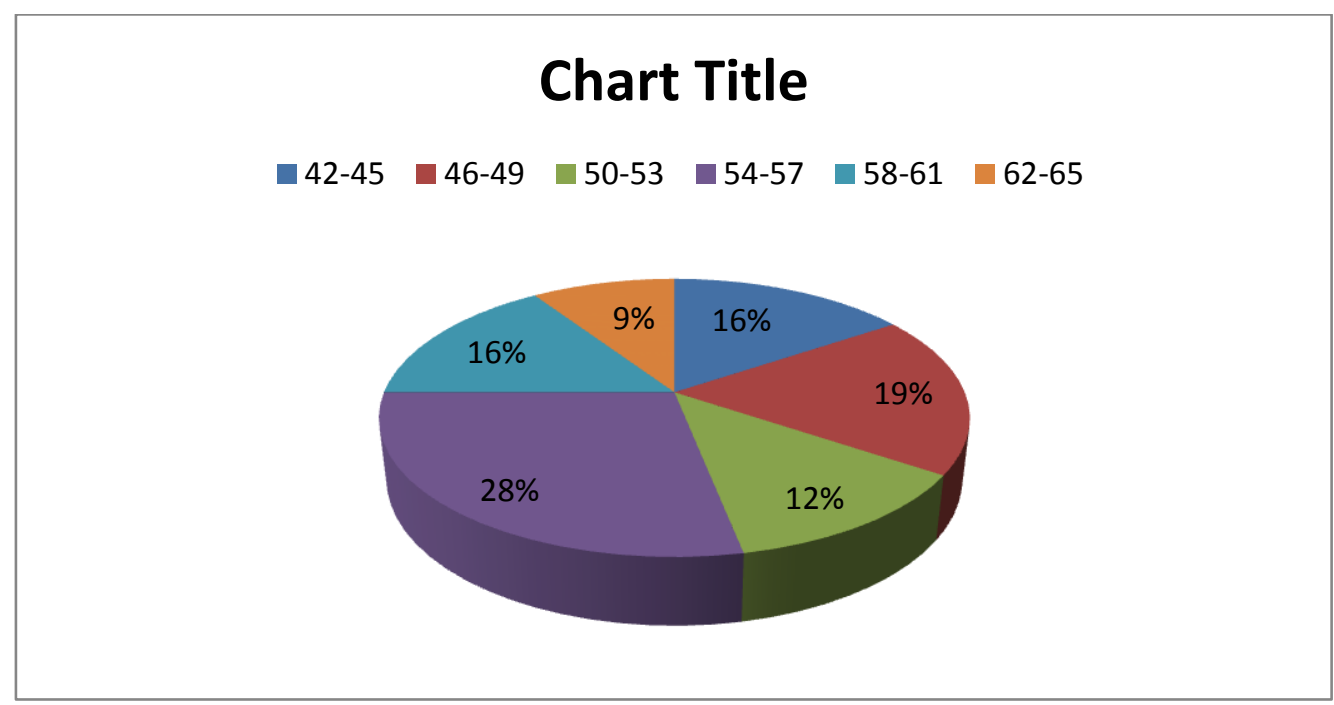

It can be seen, at the interval score of 42-45, there are $16 \%$. At the interval score 46-49 there are $19 \%$. At the interval score $50-53$, there are $12 \%$. At the interval score of 54-57, there are $28 \%$. At the interval score of $58-61$, there are $16 \%$. And at the interval score of 62-65, there are $9 \%$.

The, researcher also described the category and the percentage of students' speaking ability of telling historical experience as follows:

Table IV.2

Frequency and Percentage of Students' Speaking Ability

\begin{tabular}{cccc}
\hline Score & Category & Frequency & $\begin{array}{c}\text { Percentage } \\
\text { \% }\end{array}$ \\
\hline $\mathbf{8 0 - 1 0 0}$ & Very good & 0 & 0 \\
$\mathbf{6 6 - 7 9}$ & Good & 0 & 0 \\
$\mathbf{5 6 - 6 5}$ & Enough & 13 & 40.63 \\
$\mathbf{4 0 - 5 5}$ & Less & 19 & 59.38 \\
$\mathbf{3 0 - 3 9}$ & Fail & 0 & 0 \\
& Total & 32 & 100 \\
\hline
\end{tabular}

From the table above, it can be seen that there are 13 students at enough category, with the percentage of $40.63 \%$. There are 19 students at less category, with the percentage of 
$53.38 \%$. And there are no student at the category of very good, good, and fail category.
Meanwhile, below the researcher presents the percentage of students' score distribution.

\section{Chart IV.3}

Frequency of Students' Speaking Ability

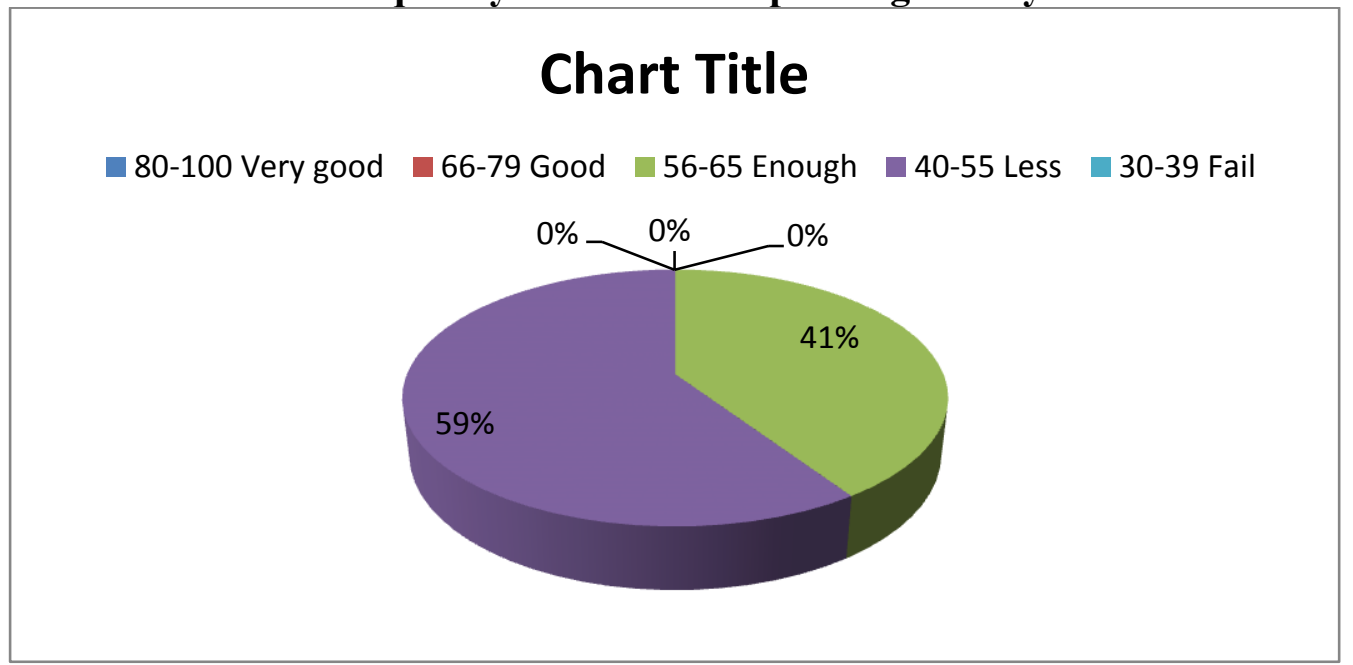

From the chart above, it can be seen that there are $41 \%$ students at the enough category and 59\% students at the less category.
B. Data Analysis of Students' Speaking Ability of Telling Historical Experience

\section{Data Analysis of Students'} Speaking Ability

For analyzing data of students' speaking ability of telling historical experience, the researcher obtained the further analysis description by using SPSS 21.0 It can be seen from the following table.

Table IV.8

Descriptive Statistics of Students' Speaking Ability Score

\begin{tabular}{lcccccc}
\hline & N & Minimum & Maximum & Mean & $\begin{array}{c}\text { Std. } \\
\text { Deviation }\end{array}$ & Variance \\
\hline Speaking Ability & 32 & 42 & 62 & 52.50 & 6.604 & 43.613 \\
Valid N (listwise) & 32 & & & & & \\
\hline
\end{tabular}

From the table it can be seen that the mean of students' speaking ability of telling historical experience is 52.50 , it means that the category for students' speaking ability is less. Next, the variance is 43.613 , the standard deviation is 6.604, minimum score is 42 , and maximum score is 62 . 
10. Data Analysis of Components of Speaking Ability

The researcher analyzed the components of students' speaking ability of telling historical experience. The analysis will be explained as follows:

Table IV.3

Analysis of Components of Speaking Ability

\begin{tabular}{ccccccc}
\hline & N & Minimum & Maximum & Mean & $\begin{array}{c}\text { Std. } \\
\text { Deviation }\end{array}$ & Variance \\
\hline Accent & 32 & 2 & 3 & 2.38 & .440 & .194 \\
Grammar & 32 & 2 & 3 & 2.66 & .448 & .201 \\
Vocabulary & 32 & 3 & 3 & 2.86 & .228 & .052 \\
Fluency & 32 & 2 & 4 & 2.42 & .510 & .260 \\
Comprehension & 32 & 2 & 3 & 2.78 & .400 & .160 \\
$\begin{array}{c}\text { Valid N } \\
\text { (listwise) }\end{array}$ & 32 & & & & & \\
\hline
\end{tabular}

From the table above, the mean score for accent is 2.38 , the mean score for grammar is 2.66 , the mean score for vocabulary is 2.86 , the mean score for fluency is 2.42 , and the mean score for comprehension is 2.78. It can be concluded that the most dominant component of students' speaking ability is comprehension. a) Accent

The researcher analyzed the students' accent of telling historical experience. The analysis will be explained as follows:

Table IV.4

Analysis of Components of Students' Accent

\begin{tabular}{cccccccc}
\hline & & Frequency & Percent & $\begin{array}{c}\text { Valid } \\
\text { Percent }\end{array}$ & $\begin{array}{c}\text { Cumulative } \\
\text { Percent }\end{array}$ & Mean & Percentage \\
\hline \multirow{4}{*}{ Valid } & 2 & 17 & 53.1 & 53.1 & 53.1 & & \\
& 3 & 6 & 18.8 & 18.8 & 71.9 & 2.38 & 47.6 \\
& 3 & 9 & 28.1 & 28.1 & 100.0 & & \\
& Total & 32 & 100.0 & 100.0 & & & \\
\hline
\end{tabular}

From the table above, it can be concluded that the mean score for Accent is 2.38, and the percentage is $47.6 \%$. b) Grammar

The researcher analyzed the students' grammar of telling historical experience. The analysis will be explained as follows: 
Table IV.5

Analysis of Components of Students' Grammar

\begin{tabular}{cccccccc}
\hline & & Frequency & Percent & $\begin{array}{c}\text { Valid } \\
\text { Percent }\end{array}$ & $\begin{array}{c}\text { Cumulative } \\
\text { Percent }\end{array}$ & $\begin{array}{c}\text { Mean } \\
\text { Score }\end{array}$ & Percentage \\
\hline \multirow{4}{*}{ Valid } & 2 & 9 & 28.1 & 28.1 & 28.1 & & \\
& 2.5 & 4 & 12.5 & 12.5 & 40.6 & & \\
& 3 & 19 & 59.4 & 59.4 & 100.0 & & 53.125 \\
& Total & 32 & 100.0 & 100.0 & & & \\
\hline
\end{tabular}

From the table above, it can be concluded that the mean score for pronunciation is 2.66, and the percentage is $53.12 \%$. c) Vocabulary

The researcher analyzed the students' vocabulary of telling historical experience. The analysis will be explained as follows:

Table IV.6

Analysis of Components of Students' Vocabulary

\begin{tabular}{cccccccc}
\hline & & Frequency & Percent & $\begin{array}{c}\text { Valid } \\
\text { Percent }\end{array}$ & $\begin{array}{c}\text { Cumulative } \\
\text { Percent }\end{array}$ & Mean & Percentage \\
\hline \multirow{3}{*}{ Valid } & 3 & 9 & 28.1 & 28.1 & 28.1 & & \\
& 3 & 23 & 71.9 & 71.9 & 100.0 & 2.86 & 57.2 \\
& Total & 32 & 100.0 & 100.0 & & & \\
\hline
\end{tabular}

From the table above, it can be concluded that the mean score for vocabulary is 2.86 , and the percentage is $57.2 \%$. d) Fluency

The researcher analyzed the students' Fluency of telling historical experience. The analysis will be explained as follows:

Table IV.7

Analysis of Components of Students' Fluency

\begin{tabular}{cccccccc}
\hline & & Frequency & Percent & $\begin{array}{c}\text { Valid } \\
\text { Percent }\end{array}$ & $\begin{array}{c}\text { Cumulative } \\
\text { Percent }\end{array}$ & $\begin{array}{c}\text { Mean } \\
\text { Score }\end{array}$ & Percentage \\
\hline \multirow{4}{*}{ Valid } & 2 & 16 & 50.0 & 50.0 & 50.0 & & \\
& 2.5 & 8 & 25.0 & 25.0 & 75.0 & & \\
& 3 & 5 & 15.6 & 15.6 & 90.6 & 2.42 & 48.4375 \\
& 4 & 3 & 9.4 & 9.4 & 100.0 & & \\
& Total & 32 & 100.0 & 100.0 & & & \\
\hline
\end{tabular}

From the table above, it can be concluded that the mean score for fluency is 2.42 , and the percentage is $48.4375 \%$. e) Comprehension

The researcher analyzed the students' Comprehension of telling historical experience. The analysis will be explained as follows: 
Table IV.7

Analysis of Components of Students' Comprehension

\begin{tabular}{cccccccc}
\hline & & Frequency & Percent & $\begin{array}{c}\text { Valid } \\
\text { Percent }\end{array}$ & $\begin{array}{c}\text { Cumulative } \\
\text { Percent }\end{array}$ & Mean & Percentage \\
\hline \multirow{4}{*}{ Valid } & 2 & 6 & 18.8 & 18.8 & 18.8 & & \\
& 3 & 2 & 6.3 & 6.3 & 25.0 & 2.78 & 55.6 \\
& & 24 & 75.0 & 75.0 & 100.0 & & \\
& Total & 32 & 100.0 & 100.0 & & & \\
\hline
\end{tabular}

From the table above, it can be concluded that the mean score for comprehension is 2.78, and the percentage is $55.62 \%$.

\section{Research Finding}

Based on the data presentation and the data analysis, the researcher find out that the mean score of students' speaking ability of telling historical experience at the tenth grade students of MA Nurul Wathan Pelangiran is 52.50.It is categorized as less level. Then, the most dominant component of students' speaking ability is vocabulary with the mean score 2.86 or $57.2 \%$.

\section{CONCLUSION AND SUGGESTION}

\section{e. Conclusion}

This research was conducted to investigate the students' speaking ability of telling historical experience at tenth grade at MA. Nurul Wathan Pelangiran. Based on what has been discussed, presented and analyzed in the previous chapters, the researcher concluded that:

1. The students' speaking ability of telling historical experience at the tenth grade students of MA Nurul Wathan Pelangiran is categorized as "less" level.

2. The dominant component of students' speaking ability in telling historical experience at the tenth grade of MA Nurul Wathan Pelangiran is "vocabulary" with mean score 2.86 or $57.2 \%$.

\section{f. Suggestion}

1. Students' speaking ability is mostly at less level. It seems the students need to prepare and practice more their speaking ability. They often pause their while speaking, or the students found it difficult to deal with vocabularies related to historical experience. Therefore, they need to enrich their vocabularies especially words related to simple past such as nouns, adverb etc. As for they mostly did their best on comprehension while speaking of their historical experience, it is good for the teacher to keep on exposing, introducing, and optimizing the topic of speaking as it can make them easily to prepare what to speak in front of the class.

2. For other researchers, it is important to choose relevant speaking topics based on what the students have learnt according to English syllabus 2013. If they hesitate about the topics, it is better to introduce or give students review about the topic, function, sentence structure, and language feature of telling historical experience such as past 
tense, adverb of time. So, they will understand how to express historical experience as expected in the standard competence of recount regarding to telling historical experience.

\section{REFERENCES}

Ali Derakhshan, A. N. (2016). Developing EFL Learner's Speaking Ability, Accuracy and Fluency. English Language and Literature Studies; Vol. 6, No. 2, 177-186.

Armasita. (2017). Improving the students' speaking skill in English Lesson by using action learning strategy at eight grade students of MTs PAB 1 Helvetia. UIN SU Medan.

Arikunto, S. (2013). Prosedur Penelitian. Jakarta: PT Renika Cipta.

Bahadorfar, M., \& Omidvar, R. (2014). Technology in Teaching Speaking Skil. Acme International Journal of Multidisciplinary Research, II,(4 ), 9-13.

Bashir, M., Azeem, M., \& Dogar, D. H. (2011). Factor Effecting Students' English Speaking Skills. British Journal of Arts and Social Sciences, 2 (1), 3450.

Brown, H. D. (2003). Language Asessment. San Fransisco: Longman.

Cohen, L. (2005). Rasearch Methods in Education. London and New York: Taylor \& Francis eLibrary.
Cohen, L., Manion, L., \& Morrison, K. (2007). Research methods in education. New York: Routledge.

Creswell, J. W. (2012). Educational Research: Planning, Conducting and Evaluating Quantitative and Qualitative Research (4th edition). New Jersey : Pearson Education,inc.

Department Pendidikan

Nasional.(2006). Pendekatan ,Strategi ,dan metode Pembelajaran. Malang: DirekturJendera 1Peningkatan Mutu pendidikan dan tenanga pendidikan.

Erfiani, Y. P. (2017). Improving Second Semester Students' Speaking Ability Through Storytelling Learning Model at English Study Program of Timor University . METATHESIS, Vol. 1, No. 2, 1-15.

Efrizal, D. (2012 ). Improving Students' Speaking through Communicative Language Teaching Method at. International Journal of Humanities and Social Science vol 2, 127-134.

Haidara, Y. (2014). Psychologycal Factor Affecting English Speaking. Proceeding International Conference on Educational Research and Evaluation (ICERE), 512-519.

Hariyadi, M. (2009). Statistik Pendidikan. Jakarta: Prestasi Pustakaraya.

Harmer, J. (2001). The Practice of English Language Teaching 
Third Edition. Cambridge: Pearson Education..

Hasibuan, K., \& Ansyari, F. (2007). Teaching English as Foreign Language. Pekanbaru: Alaf Riau Graha UNRI Press.

Hughes, A. (1989). Testing for language Teacher. New York: Press Cyndicate of University of Cambridge.

Kusmaryati, S. E. (2008). Improving English Speaking Ability Through Classroom Discussion for Sstudents of MA Nu Banat Kudus . Kudus.

Kusdianang, P. E., \& Bharati, D. L. (2016) Improving Students' Speaking Ability by Using story Retelling. EEJ 6 (1).

Lackman, K. (2010). Teaching Speaking Sub-Skill. United Kingdom: Educational Consultants.

Manurung, K. (2015). Improving the speaking skill using reading contextual internet-based instructional materials in an EFL class in Indonesia. Procedia Social and Behavioral Sciences 176, 44-51.

Nunan, D. (2007). Research Method in Language Learning. New york: Cambridge University Press.

Otoyo, K. (2018). The Use of Gallery Walk to Enhance Speaking Ability of the Eleventh Grade Students of State Madrasyah Aliyah . Jurnal Pendidikan dan Pengajaran, 1-11.
Pallant, J. (2010). A Step by Step Guide to Data Analysis Using SPSS. New York: Open University Press.

Pendidikan, K. (2016). Silabus Mata Pelajaran Sekolah Menengah Atas/Madrasah Aliyah/Skolah Menengah Kejuruan/ Madrasah Aliyah Kejuruan $=(S M A / M A / S M K / M A K)$. Jakarta: Menteri Pendidikan.

Permanasari, R. C. (2014). Improving Students' Speaking Skill Through Three Steps Interview Technique. unpublished thesis: Semarang. Semarang State University.

Priyono. (2016). Metode Penelitian Kuantitatif. Sidoarjo: Zifatama Publishing.

Rahmawati. (2017). Improving English Speaking Ability Using The Team-Games-Tournament Technique. English Education Journal (EEJ), 8(1), 1-13, 1-13.

Richards, J. C., \& Schmidt, R. (2002). Longman Dictionary of Language Teaching Applied Linguistic. London: Pearson Education.

Romlah, S. (2018). Improving Students' Speaking Skill Through Talking Stick. Research and Innovation in Language Learning Vol. 1(3) , 119-128.

Tohrnbury, S. (2005). How to Teach Speaking. New York: Longman. 
Yogi Arisandi, Harum Natasha - A Study on Student' Speaking Ability of Telling ... 